\title{
Analysis of metacognition difficulties in problem-solving static fluid material in term of Hippocrates - Galenus personality type
}

\author{
Eni Setyawati, Susilawati, Dwi Sulisworo \\ Masters in Physics Education, Postgraduate Program, Universitas Ahmad Dahlan, Yogyakarta \\ Kampus 2, Jl.Pramuka 42, Sidikan, Umbulharjo, Yogyakarta 55161 \\ Pcczalfa13@gmail.com
}

\begin{abstract}
Describing student's metacognition difficulties and thinking the process in problemsolving static fluid material in each melancholic, sanguinic, phlegmatic, and choleric (Hippocrates Galenus) personality type. This data analysis method uses a Likert scale as a measurement scale. The data analysis technique used was grouping data into four categories: Understanding The Problem, Devising A Plan, Carrying Out The Plan, Looking Back. The cause of students' metacognition difficulties caused by a lack of understanding the concept of physics, knowing symbols, formulations, notations, and calculations that will be done in each problem solving, and lack of understanding strategies in problem-solving. Students who had a melancholic, sanguinic, choleric personality type were students who had metacognition difficulties when understanding and solving the problem, and also had problems in considering strategies and realizing the use of using strategy. Students who had the Phlegmatic personality type were able to understand the problem by looking at the problem and then making an image so that it can change the information into the form of physics.
\end{abstract}

\section{Keywords: Metacognition Difficulty, Problem Solving, Hippocrates - Galenus Personality Type}

\section{Introduction}

The development of science and technology in people's lives has brought consequences for the world of education to make various adjustments immediately to be able to prepare students who are ready to compete and be able to face various complex life challenges. This is in accordance with law number 20 of 2003 concerning the national education system that national education aims to develop the potential of students to become human beings who believe and devote to the almighty god, are noble, healthy, knowledgeable, capable, creative, independent and become democratic citizens and sensitive to the challenges of the times.

It supported by karwono \& mularsih that learning is a series of activities designed to enable the learning process to occur to students. The learning contains several aspects including initiation, facilitation, and improvement of the learning process of students while the components in learning are goals, materials, activities, and evaluation of learning [1].

Today, school is no longer the dominant place for learning. Students now can learn about the universe and all phenomena from various sources, at home, community, and anywhere in any way that is different from the past. Several main trends in the learning environment affects the way of learning, namely virtualization, theme-based learning, and personal learning, with some of this trend, will provide the new insights [2]. So, the use of metacognition skills in learning is very important so that the government sets the graduate standard of high school in the 2013 curriculum must have factual, conceptual, procedural knowledge [3].

"The problem solving as a thinking process by which the learner discovers a combination of previously learned rules that he can apply to solve a novel problem" [4]. Many theories used in understanding the personality type of students. One theory that is often used and continues to be developed is the personality theory of hippocratesgalenus typology [4].

\section{Theory}

\section{A. Definition of metacognition}

"Metacognition refers to high order thinking which involves active control over the cognitive processes engaged in learning." the meaning of that sentence is the metacognition refers to high-level thinking that involves the active control of the cognitive process in learning. The component of metacognition ability in problem-solving consists of knowledge and skill components [5-6].

\section{B. Problem Solving}

Problem-solving steps include Understanding the Problem (Understanding the Problem), Making a problem-solving plan (Devising A Plan), 
Implementing the plan (Carrying Out The Plan), and checking back the results obtained (Looking Back). The conclusion is that the steps in problem-solving are Understanding the problem, Making a problemsolving plan, Implementing the solving plan that has created, Checking back the results that have been obtained or interpreting the results obtained [7].

\section{Hippocrates - Galenus personality type}

Personality divided into several types, one of that is the personality type developed by Galenus based on Hippocrates. Hippocrates states that in each person's body there are four kinds of liquids that have characteristics like the four natural elements, namely: the dry that owned by chole or yellow bile, the wet that owned by melancholy or black bile, the cold found on phlegm or mucus, the heat that owned by sanguine or blood

Furthermore, Galenus stated that these fluids were in the human body in specific proportions. According to Galenus, the personality type that owned by an individual is as follows [4] :

1. The Sanguinis Type

The character is the mood of someone emotion is always full of hope, everything at one time seen as important, but only for a while then he does not think about it anymore, feel happy to help others, friendly and cheerful person in a relationship, generally not a timid person, but if guilty it is hard to regret.

2. The Melankholis Type

The character is that all thing related to him seen as important and always accompanied by indecision, their attention mainly focused on the aspects of their difficulties, they cannot make promises easily, this also caused them to lack confidence and cannot accept the hospitality of others easily, their mood is generally too contradictory to the anguished feeling and cannot see the pleasure of others.

3. The Kholeris Type

The character is irritable but calm easily without hating. Their actions are fast but not constant, always busy, but in that busy life, they prefer to order it rather than do it themselves. Their passion is to pursue the honor, happy to be active in front of many people and likes to praised openly, wants to be generous and protect, always dressed carefully and neatly, because in this way they seemed more intellectual than they are

4. The Phlegmatic Type

The character is they do not like rushed (calm), not easily influenced, loyal.

\section{Static Fluid}

Hydrostatic pressure is the pressure that transpires under water. Hydrostatic pressure caused by immovable fluid. The hydrostatic pressure experienced by a point in the fluid caused by the fluid gravity above that point. Formulated with equations (1) [8].

$$
p_{h}=\rho g h
$$

With:

$$
\begin{aligned}
& \boldsymbol{P}=\text { Density of an object }\left(\mathrm{kg} / \mathrm{m}^{3}\right) \\
& g=\text { Gravitational acceleration }\left(\mathrm{m} / \mathrm{s}^{2}\right) \\
& \boldsymbol{h}=\text { Depth point }(\mathrm{m}) \\
& \boldsymbol{P}_{\boldsymbol{h}}=\text { Pressure (Newton) }
\end{aligned}
$$

\section{Pascal's Law}

The pressure is as a given force given divided by the area that receives the force. Can use equations (2):

$$
P=\frac{F}{A}
$$

Pascal's Law, "the pressure returned in a closed space is continued as big as the direction in all directions."Note the scheme 1 of the hydraulic mechanism above. Because the liquid cannot be added or exits the closed system, the volume of fluid pushed on the left will push the piston (solid cylinder) on the right towards the top.

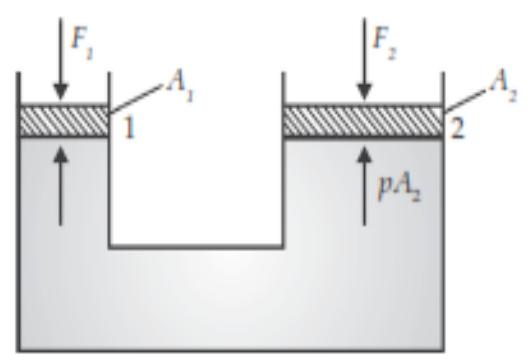

Figure1. The relationship between Cross-sectional Area and Hydrostatic Pressure on U Pipe Pascal's Law

From the picture above can be written with equation (3) and (4):

$$
\begin{aligned}
& P_{\text {in }}=P_{\text {out }} \\
& \frac{F_{1}}{A_{1}}=\frac{F_{2}}{A_{2}}
\end{aligned}
$$

With:

$$
\begin{aligned}
& P^{=}=\text {Pressure (Newton) } \\
& \boldsymbol{A}^{=} \text {Cross-sectional area (m) } \\
& \boldsymbol{F}^{=}=\text {Force (Newton) }
\end{aligned}
$$


Archimedes Law

The Archimedes Law "An object that entirely or partially submerged in a fluid lifted upward by an equal force to the weight of the fluid removed, Equation (5) written:

$$
F_{a}=\rho_{c} v g
$$

In Archimedes law, there are three possibilities:

$\rho_{b}<\rho_{c}$ The object is hovering (the object is neither rises or sinks), $\rho_{b}=\rho_{c}$ the object submerged in $\rho_{b}>\rho_{c}$.

Based on the research by Oktaviyanti (2016), the highest student misconception was the concept of the hydrostatic pressure of $(58.3 \%)$ and floating concepts $(33.3 \%)$ [9].

\section{Methodology}

This research included in the type of qualitative research. Subjects in this study were selected based on several considerations, namely: class xi students already have sufficient learning experience so that they are expected to solve the problems correctly, subjects were not randomly selected, but were chosen by considering the ability to communicate so that the disclosure of the metacognition process can take place properly. Grouping of subjects is based on personality types, namely personality types choleric, sanguinis, melancholic, and phlegmatic, totaling 25 students from 32 students.

The technique of taking subjects in this study was purposive sampling. Data collection techniques obtained through questionnaire techniques, tests, and interviews. After that, the data analyzed and validated using time triangulation. This data analysis method uses a likert scale as a measurement scale. Calculate the value of all components with the formula following equation (6) [10].

$$
P=\frac{S}{N} x 100 \%
$$

With:

$\mathrm{N}$ is the maximum number of scores

$\mathrm{S}$ is the sum of the total sub-variable scores obtained

$\mathrm{P}$ is the percentage of respondents

Table 1. An interval value of metacognition analysis

\begin{tabular}{ll}
\hline Interval $(\mathrm{P})$ & Information \\
\hline $80 \%-100 \%$ & Very (Agree, Good, Like) \\
$66 \%-79 \%$ & Agree \\
$56 \%-65 \%$ & Enough \\
$0-55 \%$ & Not Good/Disagree \\
\hline
\end{tabular}

\section{Results and Discussion}

Based on the research that has done obtained quantitative and qualitative data that covering the causes students' metacognition difficulties and data about the learning outcomes of the thinking process in problem-solving in terms of Hippocrates Galenus.

To find a description of the causes of students metacognition difficulties used descriptive data retrieval based on responses to statements in the questionnaire totaling 25 statement items.In 25 statements consisting of indicators of achievement of aspects of knowledge (declarative knowledge, procedural knowledge, conditional knowledge. Aspects of experience/skills: planning skills, predictive skills, monitoring skills, evaluation skills.

Based on the recapitulation of the results of the answers, the respondents count the average using the Likert scale with the equation (6) :

From the Likert scale calculation above, can see the results in the pie chart two below:

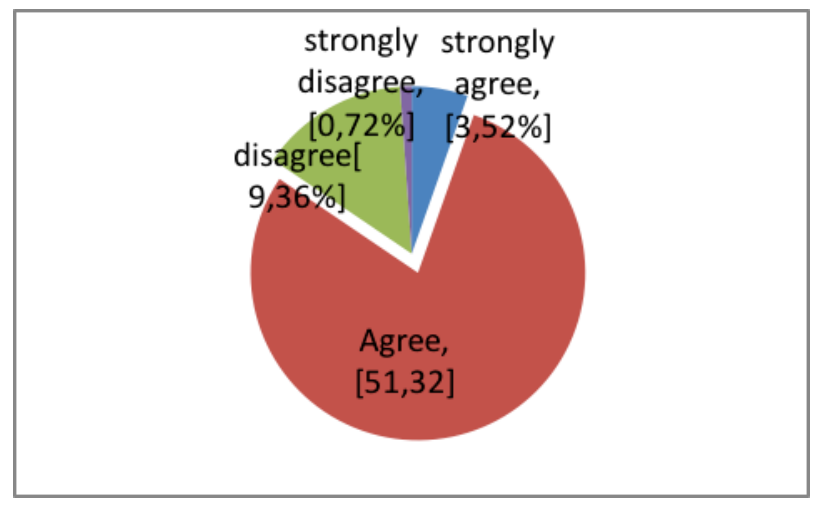

Figure 2. Results of Student's Questionnaire Analysis of Metacognition Difficulties

From the results obtained for $64.92 \%$ of respondents agreed that physics subjects are the subject that is difficult to understand. It seen from the statement items in general, including students lack understanding of the concept of physics, lack of knowledge of symbols, formulations, notation and calculations that will be done in each problem solving, and lack of understanding strategies in problems solving

The next step the researcher consulted with the counseling guidance teacher and the physics subject teacher to determine the research subject obtained static fluid material. From the results of the counseling guidance and physics teacher's consideration, students found to meet the criteria of the subject which the students could express ideas 
verbally well and able to work on the questions that accompanied by the students' thinking process [11].

From the results of the classification of personality types, it seen that there are seven students have the Melancholic personality type, five students have the Sanguinis personality type, seven students have the phlegmatic personality type, six students have the choleric personality type.From each personality type, the researcher focuses on one indicator in each type. From the results of data analysis, the following results obtained :

1. Students have Melancholic personality types

Analysis of metacognition difficulties of students have Melancholic personality type based on the metacognition process in four problem-solving steps according to Polya namely Understanding the problem, Making a problem-solving plan (Devising A Plan), Implementing the plan (Carrying Out The Plan), and re-check the results (Looking Back).

According to the theory, students have this type of personality think that everything important related to them is essential and usually accompanied by hesitation. Students attention focusses on difficulties, hard to make a promise. It can also make a lack of confidence and painful to accept the friendliness from others. The mood of their feelings generally contradicts the atmosphere of the sanguine feeling, and it is less able to see the pleasure in others. The following is a description of the difficulties of metacognition of students who have a Melancholic personality [4].

At the stage of understanding the problem of students who have Melancholic personality types, they will experience metacognition difficulties when understanding problems and solving problems. At the step of creating a problem-solving plan, students have difficulty in considering strategies and realizing the usefulness of using strategies. At the stage of carrying the plan, students have difficulties in solving problems. In the stage Looking Back result, students experience difficulties in writing things on the matter. It is because pupils do not know the concept and practice of questions about static fluid material where students only focus on the methods that have used when solving problems. Although the problem is different from the previous problem, lack of confidence of students, lack of interest and motivation in physics because the mindset of students considers that physics is a difficult subject to understand.

The questions raised in the problem-solving test are shown in Figure 3 as follows:

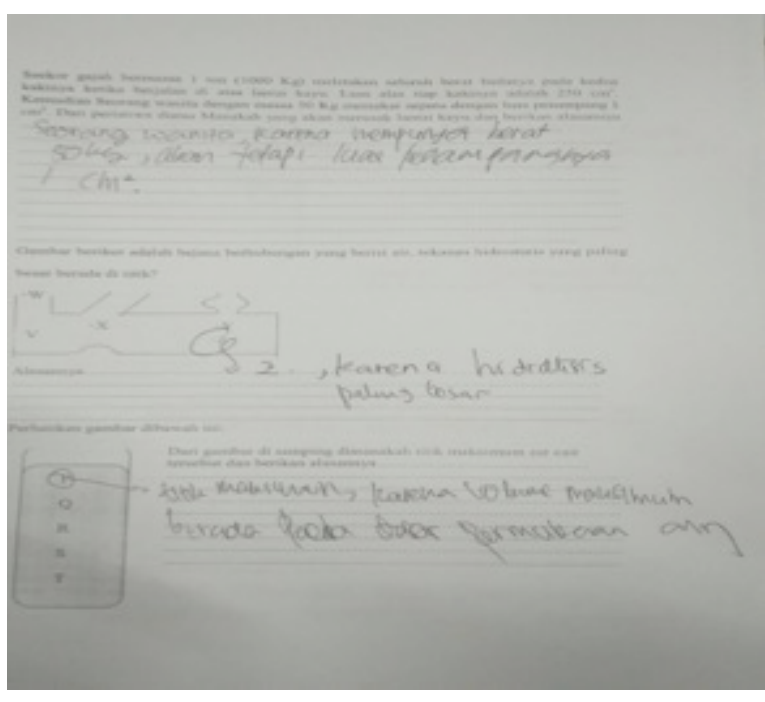

Figure 3. Problem-solving skill melancholic personality types

From Figure 3, the types of melancholic personality experienced by students explained: in case 1 student experience a misunderstanding in the material of hydrostatic pressure on solid objects where students assume that if the surface area is large then the resulting pressure is also high if the small surface area of influence is poor, being an object that has a large cross-sectional area that will damage other objects it is working on. As for the correct concept, "The magnitude of the pressure is inversely proportional to the surface area of the base of an object. The greater the surface area of an object, the smaller the pressure that caused". In the case of 2 students only from guessing letters that are in the picture, do not know what they mean but after interviewing the students, it turns out that students assume that if the cross-sectional area contained in the pipe is different then the resulting pressure is different. In case 3 for the hydrostatic pressure on the liquid, the student's answer is fixed on the top point because the pressure is very high because influenced by external air pressure.

\section{Students who have Sanguinis personality types}

Analysis of metacognition difficulties students who have a Sanguinis personality type based on the metacognition process in four problemsolving steps according to Polya (2004) namely: (1) Understanding the problem, (2) Making a problemsolving plan (Devising A Plan), (3) Carry out the plan and (4) check the results (Looking Back). 
According to the theory, students have the sanguine type of personality have a sense of feeling full of hope. Everything at one time seen as important, but a moment later they do not think about it anymore, feel happy when helping others, gentle and cheerful, in general, they are not coward, but if guilty it is hard to regret. The following is a description of the difficulties of metacognition of students who have a Sanguinis personality [4]

At the stage of Understanding the Problem, students who have a Sanguinis personality type experience difficulties in reviewing the problem. At the stage of making a problem-solving plan (devising a plan), students have difficulty in considering strategies and realizing the usefulness in using strategies. At the stage of carrying out the plan students have difficulties in solving problems. At the stage of looking back. In this case, because the students do not understand the concept and practice the exercises wherein the learning process, students focus on similar questions that often done so that in solving the problem, it is difficult. As for the questions submitted in the problem-solving test asfollowing:

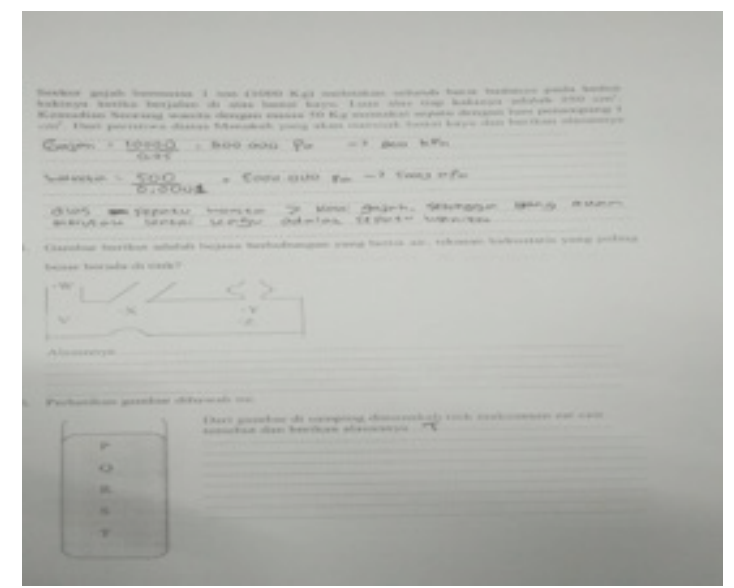

Figure 4. Problem-solving skill sanguinis personality types

From Figure 4, the types of sanguine personality experienced by students explained: in case 1 student experience a misunderstanding in the material of hydrostatic pressure on solid objects where students assume that if the surface area is large then the resulting pressure is also large if the small surface pressure area is small, being an object that has a large cross-sectional area that will damage other objects that it is working on. as for the correct concept "The amount of pressure is inversely proportional to the basic surface area of an object. The larger the surface area of an object, the smaller the pressure that caused". In the case of 2 students do not answer because students assume that on the pipe, it is difficult to determine the biggest pressure at which point. In case 3 for hydrostatic pressure on a liquid, the student's answer is correct, but the student does not know the reason why if the highest pressure is at the base of the liquid.

\section{Students have Phlegmatic personality types}

Analysis of metacognition difficulties of students who have a Phlegmatic personality type based on the metacognition process in four problemsolving steps according to Polya namely Understanding the problem, Making a problemsolving plan (Devising A Plan), Implementing the plan (Carrying Out The Plan), and Looking Back. According to theory, students with Phlegmatic personality types do not like to be careless / to be calm, difficult to influence, loyal. The following is a description of the difficulties of metacognition of students who have a Phlegmatic personality [4].

At the stage of understanding the problem, students can understand the problem when looking at the problem and then make an illustration can change information into physical form. Students have Phlegmatic personality types have no difficulty in the stage of making a problem-solving plan (Devising A Plan ), students have problems, but these difficulties can be resolved by understanding their concepts. At the stage of carrying out the plan, students can realize the difficulties when working on the problem so that students can use different strategies. As well as looking back, In withdrawing the results obtained by students, they can give conclusions appropriately and adjust the answers to an actual phenomenon.

4. Students who have the Choleric personality type

Analysis of metacognitive difficulties of students have the Choleric personality type based on the metacognition process that is on four steps of problem-solving according to the policy, namely Understanding the problem (Understanding The Problem), Making a problem solving plan (Devising A Plan), Carrying out the plan (Carrying Out The Plan), and re-examine the results obtained (Looking Back). Some literature explains that students with Choleris personality type are not flammable but are also calm, without hating, their actions are fast. But not constant, always busy, but in their busy life, he prefers to govern rather than work alone. His lust especially is pursuing honor, likes to be busy in the eyes of many people and likes to be praised openly, likes to be generous and protect, in dressing is always careful and neat, because then he appears more scholarly than he is [4].

At the stage of understanding the problem (Understanding The Problem) students have the Choleric personality type experience difficulties, 
this caused in the study of the problem. At the stage of making a problem-solving plan (devising aplan), students have difficulty in considering strategies and difficulties in realizing the usefulness of using strategies that are like what. In the carrying out The Plan phase, students have difficulty in solving problems. At the stage of re-examining, the results obtained (Looking Back) students have difficulty writing down the things listed on the question. In this case, because students do not understand the concept and lack in working on the practice of the problem in the learning process where students fixated with only the same type of problem that often done so that when solving problems often feels difficult.

Based on the description above, there are differences in the ability of students' metacognitive thinking processes. It confirmed by previous research conducted by Iswahyudi (2012), which states that students with gender differences and mathematical abilities have different metacognition activities [12]. Another research is Camelina Fitria's (2016) research which states students with different types of Guardian, Artisan, Rational and Idealist types that have different thought processes in solving problems. Two linear variables are not equal [13].

\section{Conclusion}

Based on the results of the study showed that the causes of metacognition difficulties of students of solving problems in fluid material and the thinking process of students in solving problems in static fluid material, can be explained as follows: the cause of the difficulties of metacognition of students caused by the lack of understanding the concepts of physics, knowing the symbols, formulations, notations, and calculations in each problem solving, and lack of understanding of strategies in solving problems. Students who have a melancholic, sanguine, choleric personality type have metacognitive difficulties when understanding questions and solving problems, having difficulty in considering strategies and having difficulty realizing the usefulness of using strategies. Students who have a phlegmatic personality type can understand the problem by looking at the problem then making an illustration so that they can convert information to a form of physics.

\section{Reference}

[1] Karwono and Mularsih. Metode Penelitian. Jakarta:PPM, 2010.
[2] D.Sulisworo.Conceptual Model Identification of The Personal Learning Environment.International Seminar on Education Innovation and Development in Teaching and Learning, 2014, pp. 37-41.

[3] BSNP. Standar Isi dan Standar Kompetensi Lulusan SMA/SMK. Jakarta: Kemdiknas. 2016.

[4] T. R. Astuti,Deskripsi Kemampuan Pemecahan Masalah Matematis Siswa SMA Negeri 4 Purwokerto (Ditinjau dari Tipe Kepribadian Tipologi Hippocrates- Galenus), Dissertation, Universitas Muhammadiyah Purwokerto, 2016.

[5] J. A. Livingston, Metacognition: An Overview, Education Resources Information Center, 1997.

[6] G. Polya, Howto Solve it, Princeton University Press Electronic Book, 2004.

[7] Z. C. Ozcan, Assessment of Metacognition in Mathematics: Which One of Two Methods is a Better Predictor of Mathematics Achievement?An International Online Journal of Educational Sciences, vol. 6, no. 1, 2014, pp. 49-57.

[8] P. A. Tippler. Physics for Science and Engineering Vol. 1, Erlangga, 2010.

[9] D. Oktaviyanti. Remediasi Miskonsepsi siswa menggunakan Pembelajaran Learning CYCLE 3E Pada Materi Fluida Statis di MAN. Jurnal Pendidikan dan Pembelajaran Universitas Tanjung Pura pontianak. vol.5, no.12, 2016

[10] Sugiyono. Educational Research Methods Quantitative, Qualitative Approach and $R \& D$, Alphabet Bandung, 2010.

[11] E. Setyawati. Pengaruh Strategi Konflik Kognitif Dalam Pembelajaran Fisika Terhadap Pemahaman Konsep Siswa XI IPA. Dissertation, UniversitasMuhammadiyah Metro, 2012.

[12] G. Iswahyudi, Aktivitas Metakognisi dalam Memecahkan Masalah Pembuktian Langsung Ditinjau dari Gender dan Kemampuan Matematika. Prosiding SNMPM, 2012. Pp.88-102.

[13] F. Camelian, Analysis of Student Metacognition Difficulties in Solving The Problem of Two-Variable Linear Inequality Systems in Terms of Guardian, Artisan, Rational and Idealist Personality Types in Class X of SMK 1 Jombang. Electronic Learning Mathematics Journal, vol.4, no.9, 2016, pp. 824-835. 